\title{
Bioaugmentation Strategy for Treatment of Sulfur Black Wastewater Through Sequential Fenton Oxidation and Biological Process by Two Sulfide-oxidizing Strains
}

\author{
Suyu Liu, Peng Yin, Yu Zhang, Xingke Wu, Zhiqiang Cai* \\ Laboratory of Applied Microbiology and Biotechnology, School of Pharmaceutical Engineering \& Life Science, Changzhou University, \\ Changzhou, PR China

\section{Email address:} \\ 17000181@smail.cczu.edu.cn (Suyu Liu),yinpengdevil@foxmail.com (Peng Yin),304430445@qq.com (Yu Zhang), \\ 1092678638@qq.com (XingkeWu), zhqcai@cczu.edu.cn (Zhiqiang Cai) \\ *Corresponding author
}

\section{To cite this article:}

Suyu Liu, Peng Yin, Yu Zhang, Xingke Wu, Zhiqiang Cai. Bioaugmentation Strategy for Treatment of Sulfur Black Wastewater Through Sequential Fenton Oxidation and Biological Process by Two Sulfide-oxidizing Strains. American Journal of Environmental Protection. Vol. 9, No. 3, 2020, pp. 59-66. doi: 10.11648/j.ajep.20200903.14

Received: April 27, 2020; Accepted: June 4, 2020; Published: June 17, 2020

\begin{abstract}
In order to develop an affective bioaugmentation strategy for the removal of sulfur black and increase sulfide-oxidization capability in biological treatment, bioaugmentation strains with higher sulfide-oxidizing capability, Acinetobacter sp. DS-9 and Aspergillus sp. DS-28, were isolated from a municipal wastewater (WW) treatment plant and selected to treat textile sulfur dyeing WW combined with Fenton oxidation. The sequential WW treatment process was evaluated in a bench-scale activated sludge tank. The performance of the bioreactor demonstrated the feasibility of bioaugmentation by strain DS-9 and DS-28 in terms of almost sulfur black removal, COD and color removal, significant sulfide removal in activated sludge. The effect of Fenton oxidation process, additional carbon source, bioaugmentation strains composition etc. was investigated. The bioaugmented process after Fenton oxidation and inoculation of DS-9 and DS-28 could maintain stable performance in terms of COD, color and sulfur removal from the WW. The capability of color and COD removal by bioaugmentation strains were greater than that by the original activated sludge from WW treatment plant. Sulfate concentration increased significantly from 140.5 to $485 \mathrm{mg} \mathrm{L}^{-1}$. The outlet color and COD value reach 5 and $46.52 \mathrm{mg} \mathrm{L}^{-1}$ after the sequential Fenton oxidation and bioaugmentation treatment.
\end{abstract}

Keywords: Sulfur Black Wastewater, Fenton Oxidation, Biodegradation, Bioaugmentation, Sulfide Bio-oxidization

\section{Introduction}

Sulfur dyes have a group of sulfur-containing, complex synthetic organic dyes applied from an alkaline solution of sodium sulfide to cellulose, where they become substantive to the fibre $[18,22,32]$. It is one of the largest variety of dyes in China and widely used in denim dyeing [5, 14, 18, 19, 22, 32]. Sulfur black is one of high-sulfur polymer compounds widely applied in dyeing cotton textiles. Its molecular structure was not confirmed because of the uncertain sulfur number in sulfur black (Figure 1) [5, 13, 18, 22]. During the dyeing process including dyeing agent, pre-treatment and post-cleaning, etc., a large amount of wastewater was discharged [7, 11, 18, 32]. Water consumption per ton of textile printing and dyeing is
$100-200$ tons, $80-90 \%$ of which is wastewater $[9,11]$. The dyeing WW has high chroma and COD value, and difficult to treat and decolorize $[6,8,18,19,22]$. The untreated $\mathrm{WW}$ has mutagenic and carcinogenic effects on microorganism, plants and animals $[4,12,20,26]$.

Physicochemical methods, such as adsorption, membrane filtration, photocatalyst, Fenton oxidation and advanced ozone oxidation, etc., have been studied used in the pre-treatment process before biological treatment, because the WW containing sulfur dyes has poor biodegradability and low dissolved oxygen. Then biological treatment, such as membrane bio-reactor (MBR), sequencing batch reactor activated sludge process (SBR) etc. was used in WW treatment plant $[4,6-8,10,13,14,17,19,22,29]$. Biological 
treatment often produce a large amount of activated sludge, the dried sludge after pressure filtrated was often used for incineration materials mixed with coal for power generation. However, the dried sludge contained a certain amount of sulfur from sulfur dyes, which lead to a large amount of $\mathrm{SO}_{2}$ emission into air and $\mathrm{SO}_{2}$ could cause serious acid rain.

In order to decrease sulfur content in activated sludge, Aspergillus sp. DS-28 and Acinetobacter sp. DS-9 have higher sulfur bio-oxidation capability, sulfates $\left(\mathrm{SO}_{4}{ }^{2-}\right)$ and sulfuric acid $\left(\mathrm{H}_{2} \mathrm{SO}_{4}\right)$ are generated during biological treatment using the strain DS-28 and DS-9. In this study, sequential Fenton oxidation and biological process using the strain DS-28 and DS-9 were combined and used for efficient treatment of textile dyeing WW containing sulfur black. To our knowledge, no study has been reported on sequential Fenton oxidation and sulfur bio-oxidation processes for treatment of WW containing sulfur black dyes in order to decrease sulfur concentration in sludge, which can improve efficiency of comprehensive utilization of sludge and prevent secondary pollution.

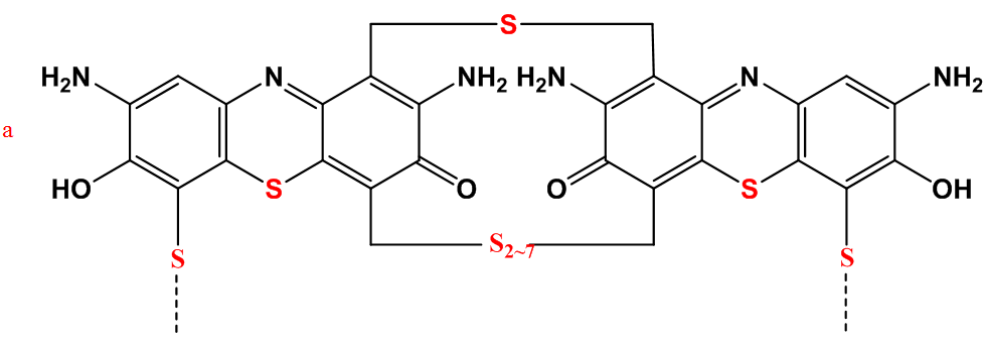

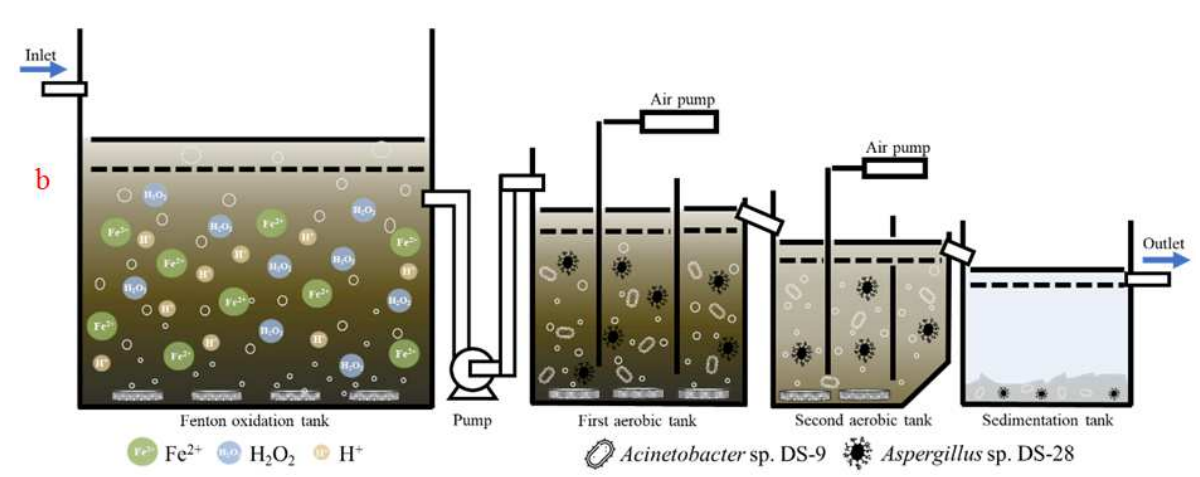

Figure 1. Molecular structure of Sulfur Black (a) and Schematic layout of sequential Fenton-biological process (b).

\section{Materials and Methods}

\subsection{Chemicals and Microorganism}

Dye of sulfur black (Figure 1a) was obtained by Black Peony (Group) Co., LTD., Changzhou, Jiangsu, China. WW was obtained from Yixing Lucky Textiles Group Co. Ltd. and WW Treatment Plant, Black Peony Group, Changzhou, China. Other chemical reagents were purchased from Sinoreagent Company and Sangon Biotech (Shanghai) Co. Ltd, and were of analytical grade and of highest purity available. Microorganisms (Acinetobacter sp. DS-9 and Aspergillus sp. DS-28) with higher capability of sulfur oxidization, were isolated from activated sludge in aerobic tank and stored in the Lab. of Applied Microbiology and Biotechnology, Changzhou University.

\subsection{Fenton Oxidation Experiments}

Fenton oxidation experiments were performed in $2 \mathrm{~L}$ tank reactor at room temperature, $100 \mathrm{rpm}$ for $0.5 .1000 \mathrm{~mL}$ of dye WW was added in glass reactor. The solution was acidified to $\mathrm{pH} 3.0$ using $1 \mathrm{M} \mathrm{H}_{2} \mathrm{SO}_{4}$. The appropriate amount of $\mathrm{Fe}_{2} \mathrm{SO}_{4} \cdot 7 \mathrm{H}_{2} \mathrm{O}$ was added and the reaction was started when the $\mathrm{H}_{2} \mathrm{O}_{2}$ was added. In order to achieve the best decolorization and COD removal effect, different ratio of
$\mathrm{Fe}_{2} \mathrm{SO}_{4} \cdot 7 \mathrm{H}_{2} \mathrm{O}$ and $\mathrm{H}_{2} \mathrm{O}_{2}$ was studied and optimized.

\subsection{Decolorization and Sulfur Biological Oxidation Experiment}

Sequential decolorization and sulfur biological oxidation experiments were performed with $2 \mathrm{~L}$ tank, two aerobic tanks and one sedimentation tank (Figure 1b). The strains of Acinetobacter sp. DS-9 and Aspergillus sp. DS-28, had higher decolorization and sulfur oxidation capability, were selected for decolorization and sulfur black degradation experiments. The inoculum was $3 \mathrm{~g} \mathrm{~L}^{-1}$. The blank experiment was carried out at the same time.

The strain D-9 and DS-28 were activated with LB medium for $24 \mathrm{~h}$, then centrifuged at $6000 \mathrm{rpm}$ for $10 \mathrm{~min}$ at $4{ }^{\circ} \mathrm{C}$. The cells were washed twice with the sterile $\mathrm{NaCl}$ solution $(0.85 \%)$. Cells were inoculated and in the tank.

The sequencing decolorization experiment was adjust $\mathrm{pH}$ value to 7.0 and stayed for $2 \mathrm{~h}$ at room temperature after Fenton oxidation. The WW from Yixing Lucky Textiles Group Co. Ltd contained COD concentration of $1800 \mathrm{mg} \mathrm{L}^{-1}$ and color chroma of 400 times, respectively. After 48-72 h, the cell grew up and the first decolorization process was finished, the WW after Fenton oxidation was spilled into the second aerobic tanks. Aeration intensity was $10 \mathrm{~mL} \min ^{-1}$ in the aerobic tank. The two reactors were joined up after the 
bacterial population had been able to degrade the sulfur black WW. Last step was sedimentation bank and the effluent from sedimentation tank was collected to measure the value of chroma, COD and sulfate concentration.

\subsection{Kinetic Analysis}

In order to estimate the decolorization and COD removal characteristics of bioaugmentation bacterial strains, Michaelis-Menten kinetics Eq. (1) was used to calculated the $V_{\max }$ and $K_{m}$.

$$
v=\frac{v_{\max } S}{S+K m}
$$

where $v$ is specific degradation rate of substrate $\operatorname{COD}\left(\mathrm{h}^{-1}\right), S$ is the substrate COD concentration $\left(\mathrm{mg} \mathrm{l}^{-1}\right), v_{\max }$ is the maximum specific degradation rate $\left(\mathrm{h}^{-1}\right), K m$ is the Monod saturation constant (i.e. substrate concentration at half $v_{\text {max }}, \mathrm{mg} \mathrm{l}^{-1}$ ).

$$
\frac{1}{v}=\frac{K m}{v_{\max }} \times \frac{1}{s}+\frac{1}{v_{\max }}
$$

Equation 2 is the linear equation, In order to estimate the degradation characteristics of bioaugmentation bacterial strains, $v_{\max }$ and $K m$ could be calculated using equation 2 .

\subsection{Analytical Method}

All analyses were carried out in accordance with Standard Methods for the Examination of Water and wastewater [25]. $\mathrm{COD}, \mathrm{pH}$, chroma, decolorization ratio and dye concentrations were monitored. Barium chromate spectrophotometry and the method of HJ/T 342-2007 were used for determining the sulfate content [21, 30]. Chemical oxygen demand (COD) was measured with potassium dichromate method [21,30]. UV-vis spectrophotometer (Gold Spectrumlab 53, Shanghai, China) was used to determine the absorbance $(A)$ and transmittance $(T)$ of the solution before and after reaction, measuring the absorbance of the solution at the maximum absorption wavelength. The decolorization rate was calculated as the formula:

$$
\text { decolorization rate }(\%)=\frac{A_{0}-A_{t}}{A_{0}} \times 100
$$

where, $A_{0}$ : initial absorbance of the solution, $A_{t}$ : absorbance of the solution at any time interval after reaction. Each decolorization experiment was performed in triplicate and mean of decolorization rate were reported.

\section{Results and Discussion}

\subsection{Fenton Oxidation of Dyeing WW Containing Sulfur Black}

As shown in Figure 2, the biodegradability of raw dyeing WW was poor due to the higher concentration of sulfur black and COD. The ratio of $\mathrm{BOD}_{5} / \mathrm{COD}(0.28)$ was relative lower than the limitation value for WW biodegradation of 0.4 , as described in previous reports [3]. Several publications showed that different factors affected COD removal ratio and decolorization efficiency of Fenton oxidation in the following order: $\mathrm{H}_{2} \mathrm{O}_{2} / \mathrm{Fe}^{2+}$ molar ratio $>\mathrm{H}_{2} \mathrm{O}_{2}$ concentration $>$ initial $\mathrm{pH}>$ reaction time $>$ temperature [28]. Thus $\mathrm{H}_{2} \mathrm{O}_{2}$ concentration, the $\mathrm{H}_{2} \mathrm{O}_{2} / \mathrm{Fe}^{2+}$ molar ratio and reaction time were investigated during the process of Fenton oxidation in this study.

Under the condition of $\mathrm{H}_{2} \mathrm{O}_{2} / \mathrm{COD}$ concentration ratio was $1.5,1.0$ and 0.5 , the $\mathrm{H}_{2} \mathrm{O}_{2} / \mathrm{Fe}^{2+}$ molar ratio was $10: 1$, $8: 1$ and $6: 1$, results of COD removal ratio was showed in Figure 2. Higher $\mathrm{H}_{2} \mathrm{O}_{2} / \mathrm{COD}$ concentration ratio and $\mathrm{H}_{2} \mathrm{O}_{2} / \mathrm{Fe}^{2+}$ molar ratio gained higher COD removal and decolorization percent, and also higher processing cost. Based on the results and chemical cost, the optimized results of Fenton oxidation were achieved with $\mathrm{H}_{2} \mathrm{O}_{2} / \mathrm{COD}$ concentration ratio of $1: 1(\mathrm{w} / \mathrm{w})$, a molar ratio of $\mathrm{H}_{2} \mathrm{O}_{2}$ to $\mathrm{Fe}^{2+}$ of $8: 1$, initial $\mathrm{pH} 3.0$ and reaction time of $60 \mathrm{~min}$. Through the Fenton oxidation process, the COD concentration decreased from $1800 \mathrm{mg} / \mathrm{L}$ to $399.16 \mathrm{mg} / \mathrm{L}$, chroma descended from 500 to 123 , respectively. COD removal ratio and decolorization rate reach $77.83 \%$ and $75.40 \%$, respectively. BOD5/COD increased significantly from 0.28 to 0.76 . The results indicated that the dyeing WW containing sulfur black could be effectively pretreated using Fenton oxidation to enhance sulfur black biodegradability.

During the Fenton-oxidation process, $\mathrm{H}_{2} \mathrm{O}_{2}$ is almost sole source of $\mathrm{HO}^{\bullet}$ and plays a very important role in the treatment of WW [28]. The optimum $\mathrm{H}_{2} \mathrm{O}_{2}$ dosage and $\mathrm{H}_{2} \mathrm{O}_{2} / \mathrm{Fe}^{2+}$ molar ratio must be determined experimentally. Insufficient $\mathrm{H}_{2} \mathrm{O}_{2}$ dosage or relative low $\mathrm{H}_{2} \mathrm{O}_{2} / \mathrm{Fe}^{2+}$ molar ratio can result in a decrease in WW treatment efficiency due to a deficiency of $\mathrm{HO}^{\bullet}$ generated. However, excessive $\mathrm{H}_{2} \mathrm{O}_{2}$ dosage or $\mathrm{H}_{2} \mathrm{O}_{2} / \mathrm{Fe}^{2+}$ molar ratio is also not encouraged because a massive amount of $\mathrm{H}_{2} \mathrm{O}_{2}$ could have a negative effect on the microbial reactivity in the subsequent bio-treatment process, and excessive $\mathrm{H}_{2} \mathrm{O}_{2}$ dosage also increase the treatment cost [28, 31].

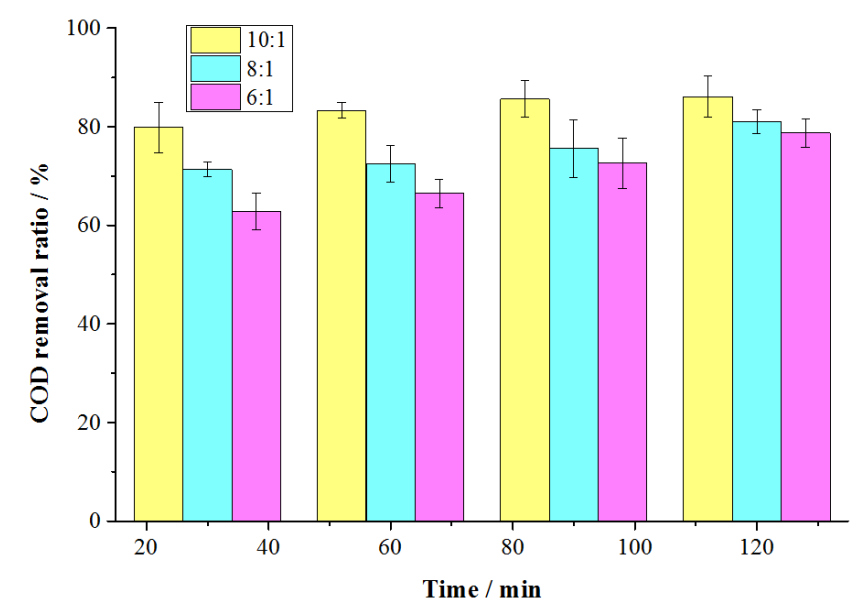



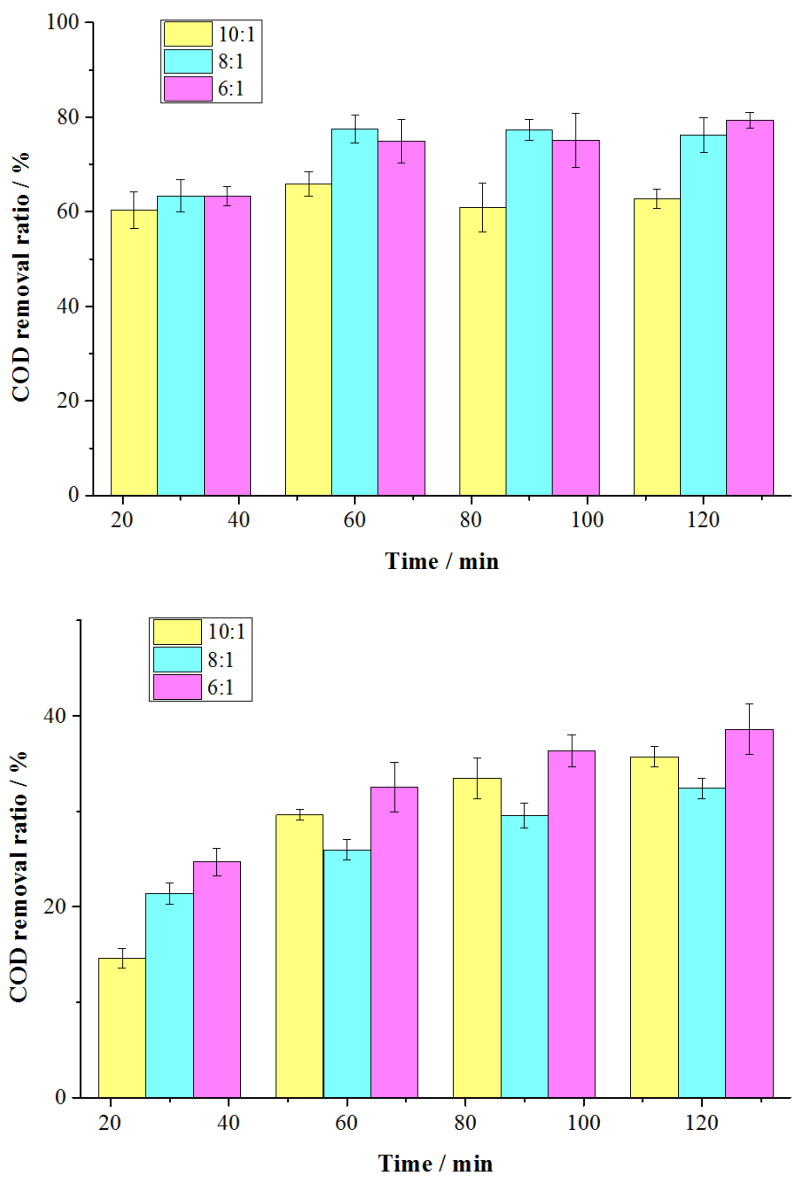

Figure 2. The effect of $\mathrm{H}_{2} \mathrm{O}_{2} / \mathrm{Fe}^{2+}$ molar ratio on COD removal ratio $\left(\mathrm{H}_{2} \mathrm{O}_{2} / \mathrm{COD}\right.$ concentration ratio 1.5 (a), 1.0 (b) 0.5 (c)). Phylogenetic tree of strain ds-28 based on the $18 S \mathrm{r}$ RNA gene homology.

\subsection{Biological Treatment of Dyeing $W W$}

\subsubsection{The Effect of Additional Carbon Source on Sulfur Oxidation Efficiency}

In order to determine the characteristics of WW containing sulfur black biodegradation, especially additional carbon source, sulfate content, the change of sulfur black molecule structure, optimal operation parameters with dyeing WW biological treatment by sulfur-oxidizing strains, Acinetobacter sp. DS-9 and Aspergillus sp. DS-28, etc. were investigated.

Three kinds of additional carbon source (glucose, sucrose and soluble starch, $500 \mathrm{mg} \mathrm{L}^{-1}$ ) was added into dyeing WW, respectively. The strain DS-9, DS-28 and bioaugmentation strains (the mixture of DS-9 and DS-28, 1:1, w/w) were also inoculated in WW, respectively. Additional carbon source (glucose, sucrose and soluble starch) can accelerate cell growth as well as the decolorization rate as shown in Figure 3. The carbon source from sulfur black was difficult to use for cell growth compared with additional carbon source in this experiment, glucose, sucrose and soluble were easily oxidized in respiration and produced ATP and other products through glycolysis and the Krebs cycle [1, 2, 23, 26]. Several reports showed that addition of significant organic carbon is desirable co-substrates for bacterial dye decolorization process $[1,2,7$, $23,26]$. In this study, the decolorization percentage of sulfur black was higher than the control and non-additional group.
Soluble starch was the best additional carbon source for the strain DS-28, and glucose was the best additional carbon source for the strain DS-9. Based on the experimental results, bioaugmentation strains showed higher decolorization capability and sulfur oxidation efficiency. The maximal COD removal ratio reach $85.47 \%$ and sulfur oxidation efficiency increased $38.85 \%$ from $1520 \mathrm{mg} \mathrm{L}^{-1}$ to $2111 \mathrm{mg} \mathrm{L}^{-1}$ after bioaugmentation strains inoculation. However the decolorization ratio, COD removal and sulfur oxidation efficiencies were relative lower under the condition of inoculation of DS-28 or DS-9 (Figure 3).
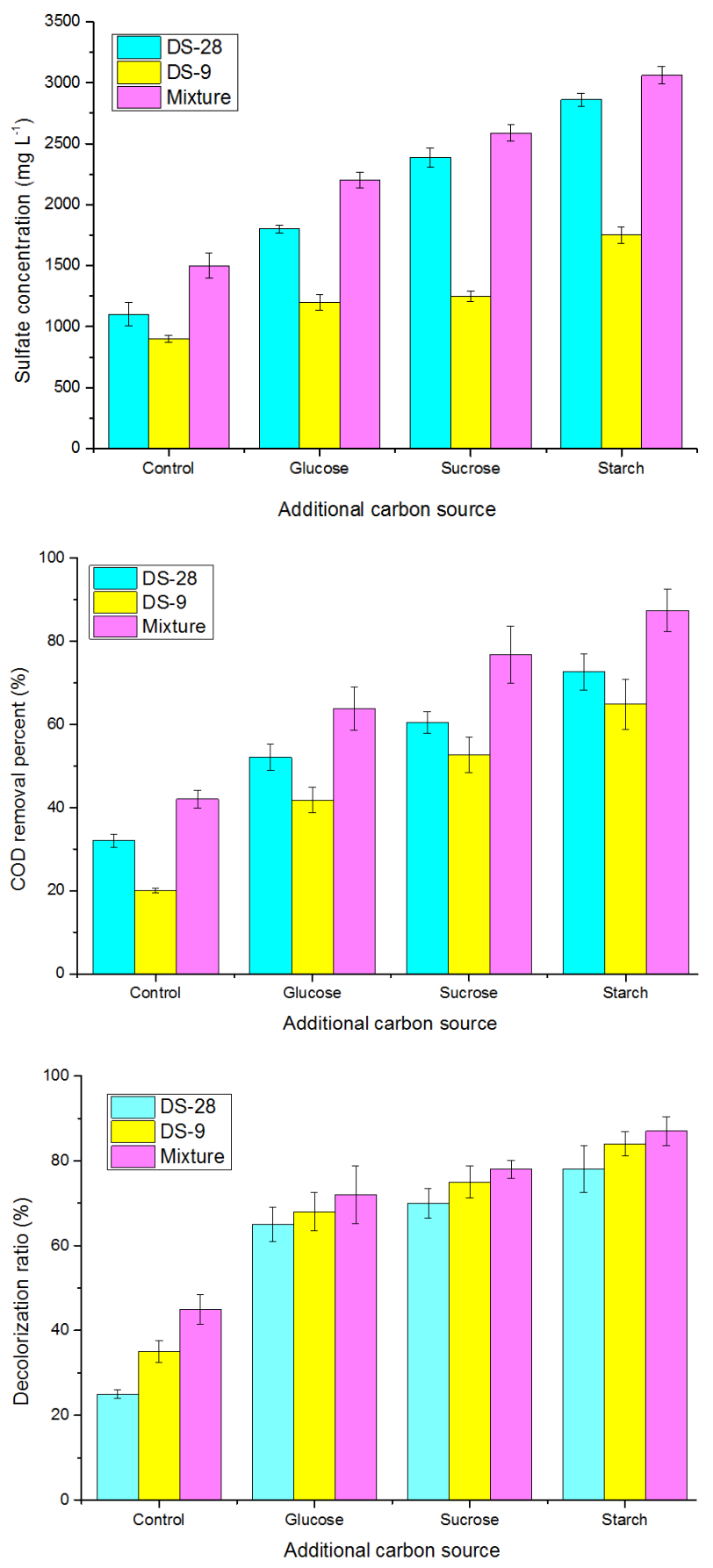

Figure 3. Effect of adding carbon source on sulfate concentration (a), COD removal percent (b) and decolorization ratio (c) by the strain DS-28, DS-9 and bioaugmentation strains. 


\subsubsection{Composition of Bioaugmentation Strains on $W W$ Treatment}

Several reports showed that bacteria composition and their ratio could affect $\mathrm{COD}$ removal ratio and decolorization efficiency etc. [6, 16, 24]. In this study in order to investigate the effect of the composition of bioaugmentation strains (ratio of strain DS-9/DS-28, w/w, 1:1, 2:1, 3:1, 1:2, 1:3) on decolorization ratio, COD removal and sulfur bio-oxidation efficiency, temperature, $\mathrm{pH}$, and starch concentration were kept constant at $28^{\circ} \mathrm{C}, 7.2$, and $500 \mathrm{mg} \mathrm{L}^{-1}$, respectively, for 5 days, while different ratio of strain DS-9 to strain DS-28 was inoculated into the reactor. Figure 4 depicted that as the sulfur oxidation strains composition (DS-9:DS-28, w:w, 1:1, 2:1, 3:1) changed from $1: 1$ to $3: 1$, sulfate concentration increased significantly from $4201.8 \mathrm{mg} \mathrm{L}^{-1}$ to $4661.2 \mathrm{mg} \mathrm{L}^{-1}$, while it was only $3100 \mathrm{mg} \mathrm{L}^{-1}$ in the control group. The cell growth rate was relatively rapid under the condition of $3: 1$ composition (data not shown), and COD removal percent reach maximum, however, decolorization ratio was only $90 \%$. When the strain DS-9/DS-28 ratio was $1: 2$, COD removal percent and sulfate concentration decreased sharply, and decolorization ratio increased. Similar observations have been recorded earlier for decolorization, strain DS-9 was belonged to the family of Acinetobacter sp., strain DS-28 was Aspergillus sp. [16, 24]. The content and ratio of Aspergillus sp. DS-28 increased, the capability of absorb dye also increased, therefore the decolorization ratio increased, and COD removal percent and sulfate concentration decreased. The figure 5 showed that the strain DS-28 could absorb sulfur black during decolorization process. Many reports showed that fungus could absorb dyeing during dyeing WW bio-treatment $[15,16]$, at the meanwhile, fungus also can express and secrete dye degradative enzymes to degrade dyes $[6,15,16]$. Therefore, selection of these two species for bioaugmentation was beneficial for enhancement of biodegradation of sulfur black. Several intermediates of sulfur black were also monitored and identified by LC-LC/MS (Figure 6) and the biodegradation pathway was proposed (Figure 7), revealing that the bioaugmentation bacteria was superior to the non-augmented for all effluent quality parameters analyzed (Figures 2, 3, 4, Tables 1, 2).

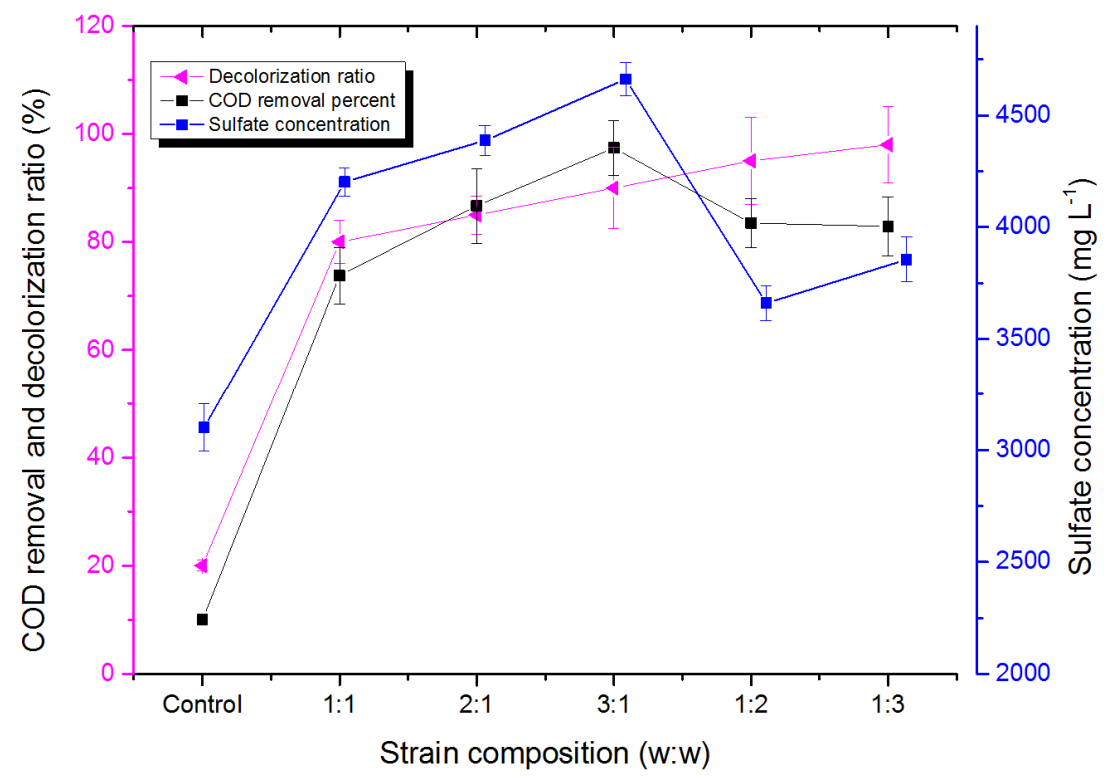

Figure 4. The Effect of Composition of bioaugmentation strains on wastewater biological treatment.

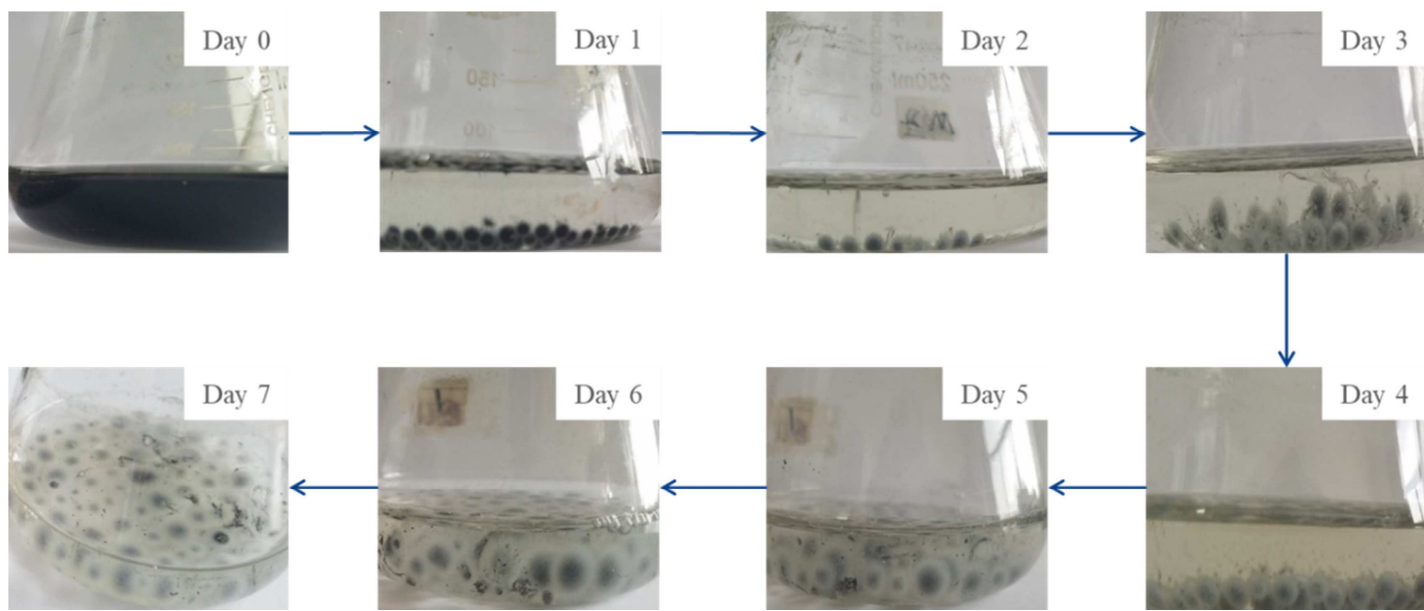

Figure 5. The Change of decolorization process by the strain of Aspergillus sp. DS-28. 


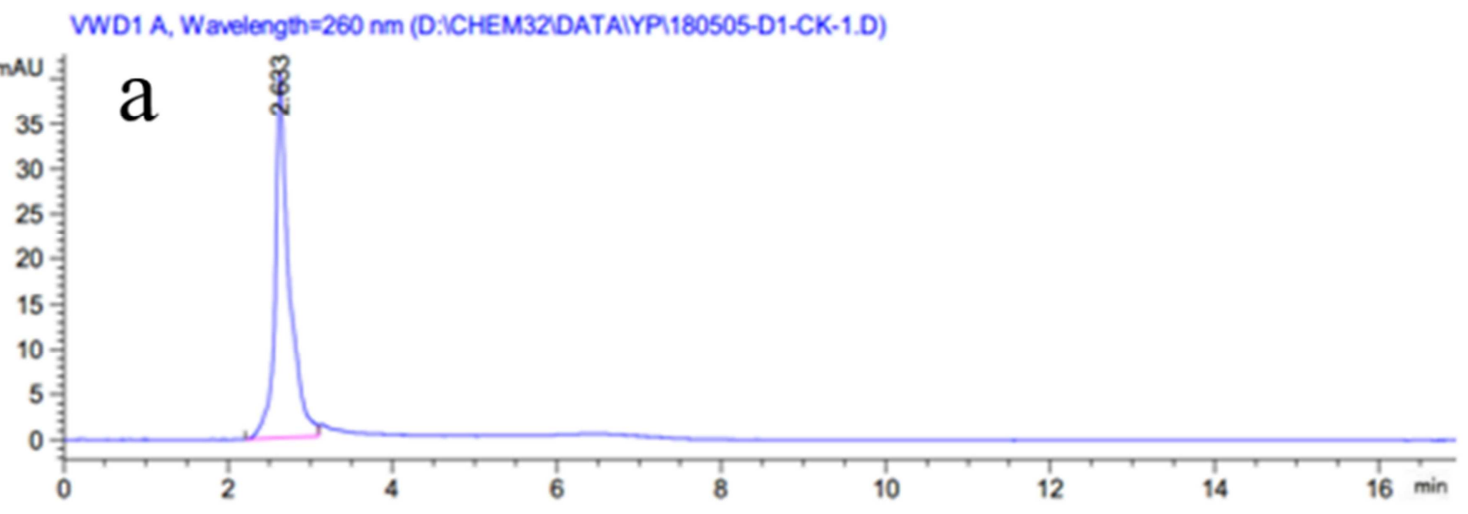

WWD1 A. Wavelength $=260 \mathrm{~nm}$ (D.ACHEM32VDATAIYP180511-D7-DS9-2.D)

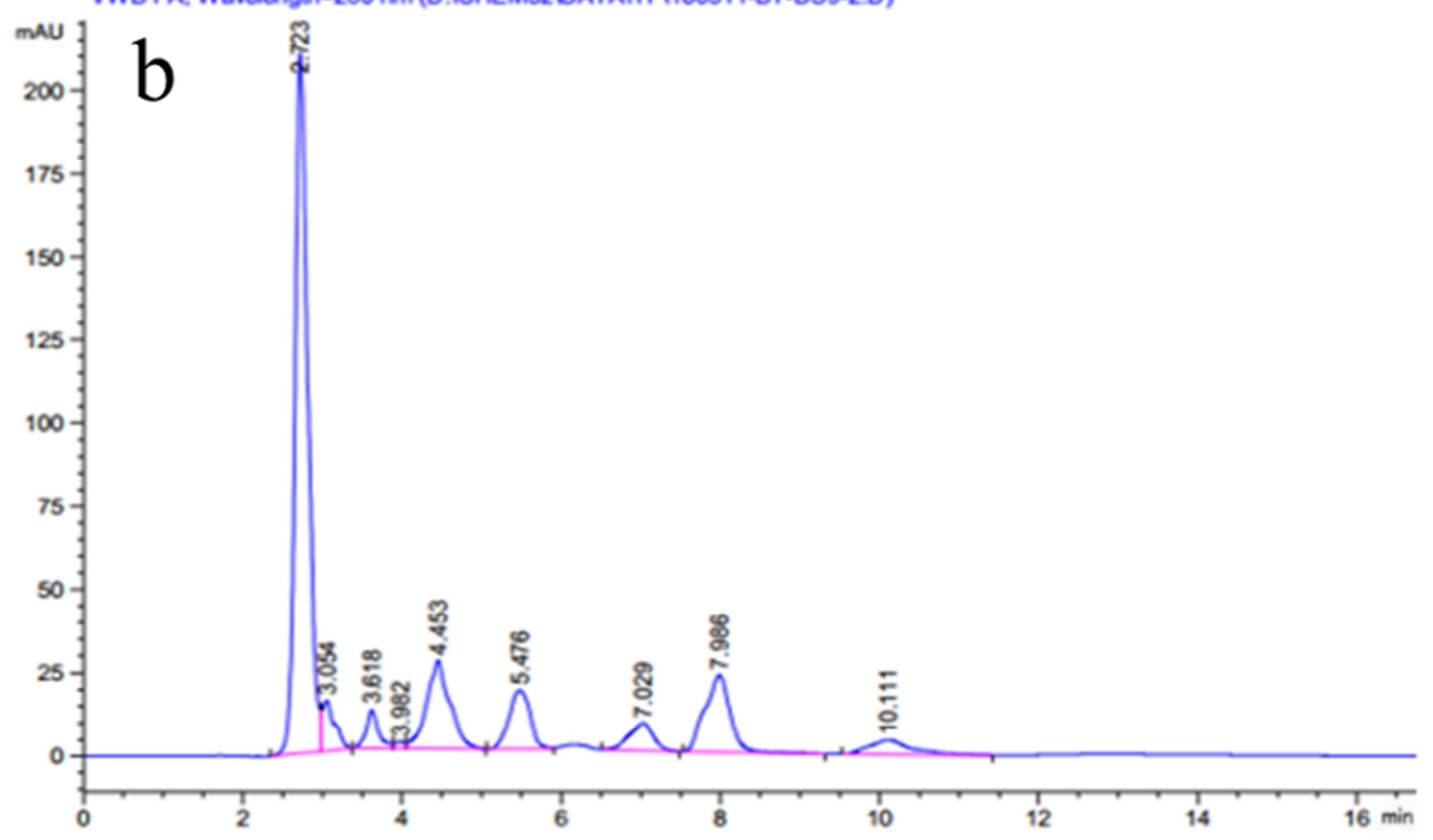

Figure 6. LC-LC / MS diagram of sulfur black before (a) and after (b) treatment biological treatment.

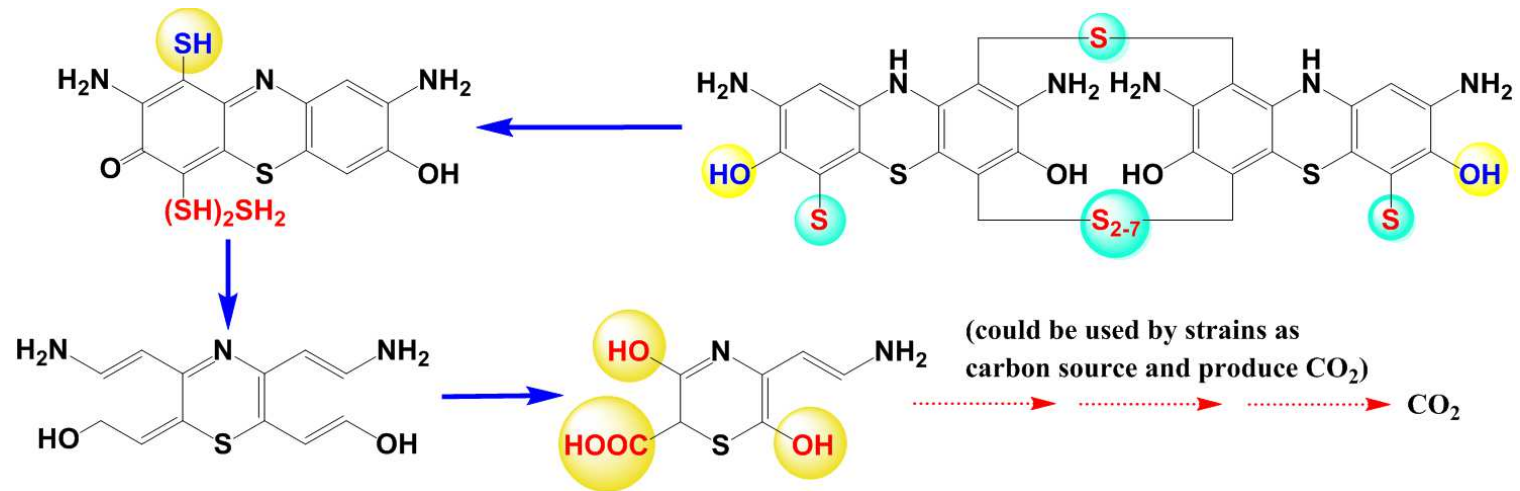

Figure 7. The proposed biodegradation pathway by the bioaugmentation strains.

Table 1. The results of dye wastewater containing sulfur black sequential Fenton-Biological treatment.

\begin{tabular}{|c|c|c|c|c|c|c|c|c|}
\hline Treatment process & $\begin{array}{l}\text { Inlet } \\
\text { chroma } \\
\text { (times) }\end{array}$ & $\begin{array}{l}\text { Outlet } \\
\text { chroma } \\
\text { (times) }\end{array}$ & $\begin{array}{l}\text { Color } \\
\text { removal } \\
(\%)\end{array}$ & $\begin{array}{l}\text { Inlet COD } \\
\left(\mathrm{mg} \mathrm{L}^{-1}\right)\end{array}$ & $\begin{array}{l}\text { Outlet COD } \\
\left(\mathrm{mg} \mathrm{L}^{-1}\right)\end{array}$ & $\begin{array}{l}\text { COD } \\
\text { removal } \\
(\%)\end{array}$ & $\begin{array}{l}\text { Inlet } \\
\text { Sulfate } \\
\text { concentrati } \\
\text { on }\left(\mathrm{mg} \mathrm{L}^{-1}\right)\end{array}$ & $\begin{array}{l}\text { Outlet } \\
\text { Sulfate } \\
\text { concentrati } \\
\text { on }\left(\mathrm{mg} \mathrm{L}^{-1}\right)\end{array}$ \\
\hline Fenton oxidation tank & $500 \pm 30$ & $113 \pm 10$ & 77.40 & $1800 \pm 120$ & $399.16 \pm 15$ & 77.82 & - & - \\
\hline The first aerobic biological tank & $113 \pm 10$ & $15 \pm 4$ & 86.73 & $399.16 \pm 15$ & $108.7 \pm 9.5$ & 72.76 & $140.5 \pm 11$ & $392 \pm 25$ \\
\hline The second aerobic biological tank & $15 \pm 4$ & $5 \pm 1$ & 66.67 & $108.7 \pm 9.5$ & $46.52 \pm 5$ & 55.36 & $392 \pm 25$ & $485 \pm 32$ \\
\hline
\end{tabular}


Table 2. Kinetic parameters evaluated for bioaugmentation strains of COD and sulfate concentration.

\begin{tabular}{lllll}
\hline & $\boldsymbol{K} \boldsymbol{m}\left(\mathbf{m g ~ \mathbf { L } ^ { - 1 }}\right)$ & $\boldsymbol{v}_{\max }\left(\mathbf{h}^{-1}\right)$ & $\mathbf{R}^{\mathbf{2}}$ & Michaelis-Menten Equation \\
\hline COD concentration & 116.28 & 829.97 & 0.9832 & $v=829.97$ X S/(S+116.28) \\
Sulfate concentration & 151.52 & 960.78 & 0.9991 & $v=960.78$ X S/(S+151.52) \\
\hline
\end{tabular}

\subsection{Sequential Batch Treatment Through Fenton Oxidation and Biological Treatment}

The overall color and COD removal ratio were above 95\% through sequential Fenton oxidation and biological processes. Sulfate concentration also increased $70 \%$ from $120 \mathrm{mg} \mathrm{L}^{-1}$ to $485 \mathrm{mg} \mathrm{L}^{-1}$. During the Fenton oxidation treatment, $\mathrm{H}_{2} \mathrm{O}_{2} / \mathrm{COD}$ concentration ratio and molar ratio of $\mathrm{H}_{2} \mathrm{O}_{2}$ to $\mathrm{Fe}^{2+}$ were $1: 1$ $(\mathrm{w} / \mathrm{w})$ and $8: 1$, respectively, initial $\mathrm{pH}$ value was adjusted to 3.0 and reaction time was $60 \mathrm{~min}$. The COD concentration decreased from $1800 \mathrm{mg} / \mathrm{L}$ to $399.16 \mathrm{mg} / \mathrm{L}$, chroma descended from 500 to 113 , respectively. COD removal ratio and decolorization rate reach $77.82 \%$ and $77.4 \%$, respectively. Table 1 showed that the color removal, COD reduction and sulfate generation in first and second aerobic tank. In the first aerobic biological process, the outlet COD value decreased from 400 to $108 \mathrm{mg} \mathrm{L}^{-1}$, COD removal reached $72.76 \%$, sulfate concentration increased from 140.5 to $392 \mathrm{mg} \mathrm{L}^{-1}$ by bioaugmentation bacterial strains. And in the second aerobic biological process, the COD of outlet water was only 46.52 , color chroma was 5 . The sulfate concentration reaches 485 $\mathrm{mg} / \mathrm{L}$.

The capability of color and COD removal by bioaugmentation bacterial strains were greater than that by original activated sludge from WW treatment plant. Sulfate concentration increased significantly, from 140.5 to $485 \mathrm{mg}$ $\mathrm{L}^{-1}$. The outlet color and COD value reach 5 and $46.52 \mathrm{mg} \mathrm{L}^{-1}$ after the second biological process by the strains, which was sufficient meet China standards for discharge (a fixed emission standard of $60 \mathrm{mg} \mathrm{L}^{-1} \mathrm{COD}$ and 20 color is required in south of Jiangsu Province, China).

From the results obtained in this study, kinetic analysis was performed using Michaelis-Menten kinetics models. Decolorization removal and sulfate concentration increased are the main indicators, which were used to assess the efficiency of the decolorizing process. According Micchaelis-Menten kinetics equation were calculated as in Table 2. It is clear that Michaelis-Menten kinetics model gives a good correlation and kinetic analysis was performed used Mechaelis-Menten kinetics equation. The table 2 demonstrated that the $K m$ and $v_{\max }$ of COD and sulfate concentration were both good correlation. The $\mathrm{Km}$ and $v_{\max }$ of COD concentration were $116.26 \mathrm{mg} \mathrm{L}^{-1}$ and $829.97 \mathrm{~h}^{-1}$, and $\mathrm{Km}$ and $v_{\max }$ of sulfate concentration were $151.52 \mathrm{mg} \mathrm{L}^{-1}$ and $960.78 \mathrm{~h}^{-1}$, which illustrated that COD removal and sulfur bio-oxidation were occurred at almost same time, and the bioaugmentation strain (mixture of DS-28 and DS-9) had higher capability with sulfur bio-oxidation.

\section{Conclusions}

In the present study, a sequential Fenton oxidation and bioaugmentation process was developed and employed for efficient treatment of textile dyeing WW containing sulfur black. The bioaugmentation bacteria (mixture of Acinetobacter sp. DS-9 and Aspergillus sp. DS-28) with higher capability of sulfur oxidization was used for bioaugmentation potential. The study of the effect of some factors of Fenton oxidation and biological treatment showed that increase in $\mathrm{H}_{2} \mathrm{O}_{2} / \mathrm{Fe}^{2+}$ molar ratio enhanced the decolorization efficiency and COD removal ratio. Amendment of dying WW with up to $500 \mathrm{mg} \mathrm{L}^{-1}$ soluble starch increase decolorization efficiency, sulfur bio-oxidation capability and degradation rate, whereas further increase did not have any effect. The composition of bioaugmentation strains structure also can affect sulfur bio-oxidation and decolorization efficiency. The results in this study will provide technical support for sulfur dyeing WW deep and harmless treatment, and it also provide theoretical guidance for decreasing the sulfur content in activated sludge and other similar studied of other pollutants containing sulfur.

\section{Conflict of Interest}

All the authors do not have any possible conflicts of interest.

\section{References}

[1] Abiri F, Fallah N, Bonakdarpour B (2017) Sequential anaerobic-aerobic biological treatment of colored wastewaters: case study of a textile dyeing factory wastewater. Water Science and Technology 75 (5-6): 1261-1269.

[2] Adikane HV, Dange MN, Selvakumari K (2006) Optimization of anaerobically digested distillery molasses spent wash decolorization using soil as inoculum in the absence of additional carbon and nitrogen source. Bioresource Technology 16: 2131-2135.

[3] Al-Momani F, Touraud E, Degorce-Dumas JR, Roussy J, Thomas O (2002) Biodegradability enhancement of textile dyes and textile wastewater by VUV photolysis. Journal of Photochemistry and Photobiology A-Chemistry. 153: 191-197.

[4] Banat IM, Nigam P, Singh D, Marchant R (1996) Microbial decolorization of textile-dye-containing effluents: A review. Bioresoure Technology 3: 217-227.

[5] Bolton R (1991) Phenazine, oxazine, thiazine and sulfur dyes. Second supplements to the 2nd editon of Rodd's Chemistry of Carbon Compounds. 4: 173-201.

[6] Cai ZQ, Huang L, He YC, Shi S, Zhao XY, Wang LQ, Wang L (2012) Enzyme Catalysis and Decolourisation of Brilliant Reactive Red X-3b by Azoreductase from a Newly Isolated Pseudomonas Putida WLY. Biology and Environment-Proceedings of the Royal Irish Academy 112b (3): 293-300. 
[7] Cai ZQ, Ma JT, Wang J, Cai JY, Yang GH (2016) Biodegradation of dye-containing wastewater by fusant strains using a sequential anaerobic-aerobic process. Desalination and Water Treatment 40: 18888-18896.

[8] Chacko JT, Subramaniam K (2011) Enzymatic Degradation of Azo Dyes - A Review. International Journal of Environmental Sciences 6: 1250-1260.

[9] Chen H, Li X, Xue G, Gao P, Liu ZH, Liu YN (2015) Key issues in the current printing and dyeing wastewater treatment. Industrial Water Treatment 10: 16-19.

[10] Fan LS, Zhang NQ, Sun KN (2014) Recovering energy from dye wastewater for a new kind of superior supercapacitor material. RSC Advances 41: 21419-21424.

[11] Franciscon E, Zille A, Dias GF, Ragagnin de MC, Durrant LR, Cavaco-Paulo A (2009) Biodegradation of textile azo dyes by a facultative Staphylococcus arlettae strainVN-11 using a sequential microaerophilic/aerobic process. International Biodeterioration \& Biodegradation 63: 280-288.

[12] Gita S, Shukla SP, Saharan N, Prakash C, Deshmukhe G (2019) Toxic Effects of Selected Textile Dyes on Elemental Composition, Photosynthetic Pigments, Protein Content and Growth of a Freshwater Chlorophycean Alga Chlorella vulgaris. B. Bulletin of Environmental Contamination and Toxicology 102 (6): 795-801.

[13] Han RL, Zhang SH, Zhao WY, Li XD, Jian XG (2009) Treating sulfur black dye wastewater with quaternized poly (phthalazinone ether sulfone ketone) nanofiltration membranes Separation and Purification Technology 1: 26-30.

[14] Kadam AA, Telke AA, Jagtap AS, Govindwar SP (2011) Decolorization of adsorbed textile dyes by developed consortium of Pseudomonas sp. SUK1 and Aspergillus ochraceus NCIM-1146 under solid state fermentation. Journal of Hazardous Matererials 1: 486-494.

[15] Khan R, Bhawana P, Fulekar MH (2013) Microbial decolorization and degradation of synthetic dyes: a review. Reviews in Environmental Science and Biotechnology 12: 75-97.

[16] Kulkarni AN, Watharkar AD, Rane NR, Jeon BH, Govindwar SP (2018) Decolorization and detoxification of dye mixture and textile effluent by lichen Dermatocarpon vellereceum in fixed bed upflow bioreactor with subsequent oxidative stress study. Ecotoxicology and Environmental Safety. 148: 17-25.

[17] Lee EY, Cho KS, Ryu HW (2000) Characterization of sulfur oxidation by an autotrophic sulfur oxidizer, Thiobacillus sp. ASWW-2. Biotechnology and Bioprocess Engineering 5: 48-52.

[18] Lin S, Mackey HR, Hao T, Guo G, van Loosdrecht MCM, Chen G (2018) Biological sulfur oxidation in wastewater treatment: A review of emerging opportunities. Water Research 143: 399-415.

[19] Liu C, Gao S, Zhao Y (2012) Sulfur dye and its application prospect. Shandong Textile Science and Technology 3: 46-49.
[20] Mansour HB, Houas I, Montassar F, Ghedira K, Barillier D, Mosrati R, Chekir-Ghedira L (2012) Alteration of in vitro and acute in vivo toxicity of textile dyeing wastewater after chemical and biological remediation. Environmental Science and Pollution Research 7: 2634-2643.

[21] Namgung HK, Ahn H, Song J (2012) Development of a two-phase bioreactor for the biological removal of hydrogen sulfide from biogas. 2nd International Conference on Advances in Energy Engineering (ICAEE) 14: 1143-1148.

[22] Nguyen TA, Fu CC, Juang RS (2016) Biosorption and biodegradation of a sulfur dye in high-strength dyeing wastewater by Acidithiobacillus thiooxidans. Journal Environmental Management 182: 265-271.

[23] Palanivelan R, Rajakumar S, Ayyasamy PM (2014) Effect of various carbon and nitrogen sources on decolorization of textile dye remazol golden yellow using bacterial species. Journal of Environmental Biology 35 (5): 781-787.

[24] Patil SM, Suryavanshi MV, Chandanshive VV, Kurade MB, Govindwar SP, Jeon BH (2020) Regeneration of textile wastewater deteriorated microbial diversity of soil microcosm through bioaugmentation. Chemical Engineering Journal 380: 122533 .

[25] Rice EW, Baird RB, Eaton AD (2017) Standard Methods for the Examination of Water and Wastewater. American Public Health Association, American Water Works Association, Water Environment Federation.

[26] Sarkar S, Banerjee A, Halder U, Biswas R, Bandopadhyay R (2017) Degradation of synthetic azo dyes of textile industry: a sustainable approach using microbial enzymes. Water Conservation Science and Engineering 4: 121-131.

[27] Vijayaraghavan G, Shanthakumar S (2015) Removal of Sulfur Black Dye from its Aqueous Solution Using Alginate from Sargassum sp (Brown Algae) as a Coagulant. Environmental Progress \& Sustainable Energy 5: 1427-1434.

[28] Wang N, Zheng T, Zhang G, Wang P (2016) A review on Fenton-like processes for organic wastewater treatment. Journal of Environmental Chemical 4: 762-787.

[29] Wu DL, Wang W, Guo QW, Shen YH (2013) Combined Fenton-SBR process for bamboo industry wastewater treatment. Chemical Engineering Journal 214: 278-284.

[30] Zeng Q, Hao T, Mackey HR, Wei L, Guo G, Chen G (2017) Alkaline textile wastewater biotreatment: a sulfate-reducing granular sludge based lab-scale study. Journal of Hazardous Matererials 332: 104-111.

[31] Zhang L, Su F, Wang N, Liu S, Yang M, Wang YZ, Huo D, Zhao T (2019) Biodegradability enhancement of hydrolyzed polyacrylamide wastewater by a combined Fenton-SBR treatment process. Bioresource Technology 278: 99-107.

[32] Zhou X, Tang Y (2018) Development trend of China's dye industry from 2018 to 2022. Dyestuffs and Coloration 55: $11-23$. 